\title{
Attitude of Veterinary Students to Cadaveric Dissection in Teaching and Learning Veterinary Anatomy in the Caribbean
}

\author{
Reda Mohamed \\ Department of Basic Veterinary Sciences, School of Veterinary Medicine, Faculty of Medical \\ Sciences, The University of the West Indies, St. Augustine, Republic of Trinidad and Tobago \\ Department of Anatomy and Embryology, Faculty of Veterinary Medicine, Beni-Suef \\ University, Beni-Suef 62511, Egypt
}

Tel: 645-3232-4206Ｅ-mail: kkidareda@gmail.com

Received: February 15, 2020 Accepted: March 26, 2020 Published: March 29, 2020

doi: 10.5296/ire.v8i1.16761 URL: https://doi.org/10.5296/ire.v8i1.16761

\begin{abstract}
Teaching practical veterinary anatomy using animal cadavers poses many challenges. The aim of this study was to evaluate the attitude of veterinary students towards animal cadaver dissection as a learning and teaching tool for veterinary anatomy. The study sample comprised of 57 students who passed the veterinary anatomy courses at school of veterinary medicine at The University of the West Indies, Trinidad and Tobago. A questionnaire with 13 close-ended questions was prepared and distributed to the students. The results were collected and analyzed. The results showed that most of the students agreed about the importance of dissection of animal cadavers in teaching, learning and studying of veterinary anatomy. They preferred to dissect animal cadavers over the use of prosected specimens during practical sessions. As the former one allowed more hands on interaction with real structures and organs as well as the development of practical skills necessary for actual surgery. On the hand, most of the students disagreed with replacing the animal cadavers with plastic models or using computer assisted demonstrations. This study concluded that animal cadaveric dissection is an effective method of teaching in delivering veterinary anatomy knowledge and in developing surgical skills.
\end{abstract}

Keywords: Attitude, Cadaver, Dissection, Veterinary students

\section{Introduction}

Veterinary anatomy is taught to undergraduate veterinary students via theoretical and 
practical sessions. Teaching of academic subjects such as anatomy requires an array of teaching methods to facilitate the various learning styles of students. Traditionally, practical veterinary anatomy is taught via dissection of animal cadavers and demonstrations using prosections. Internationally, animal cadavers are used as a learning tool for veterinary students to acquire knowledge and clinical skills (Woon, 2010), dissection elaborates and reinforces the theoretical knowledge and remains very important in learning anatomy (McLachlan, Bradley, \& Searle, 2004; Bharadwaja \& Aman, 2017). However, using cadavers in teaching anatomy is associated with particular challenges such as exposure to formalin, obtaining ethical approvals, sourcing of animal cadavers and storage of dissected specimens (Gummery, Cobb, Mossop, \& Cobb, 2018). Also, dissection of cadavers is time consuming and potentially harmful (Dinsmore et al., 1999). Further, there is no evidence of the efficacy of cadaveric dissection on clinical practice or real life (Mclachlan, 2004), so much so, virtual dissection tables replaced cadaveric dissection in some institutions (Azis, Mckenzie, Wilson, Cowie, Ayeni, \& Dunn, 2002). Additionally, multimedia devices make anatomy more pleasurable and prevents the killing of animals by dissection (Ozkadif \& Eken, 2012). The purpose of the current study was to evaluate the veterinary students' attitude towards the dissection of animal cadavers for teaching and learning of veterinary gross anatomy.

\section{Methods}

The study was conducted with the use of a questionnaire, which comprised of 13 closed (yes/no) questions. It was administered to 57 veterinary students who had already completed and passed the veterinary anatomy courses at the School of Veterinary Medicine, Faculty of Medical Sciences, The University of the West Indies, Trinidad and Tobago. Students were selected randomly and they were informed about the purpose of the study. The students who repeated the course were excluded from the study. The students were given one week to answer the questions. The students in the sample were taught using the dissection of dog cadavers as well as previously dissected cadavers demonstrated by the lecturer. The cadavers that were used for dissection were obtained from the Trinidad and Tobago Society for the Prevention of Cruelty to Animals (TTSPCA) whenever they had animals with untreatable conditions. The data was collected from the questionnaire and analyzed using Microsoft Excel.

\section{Results}

The results of the survey indicated that $86 \%$ of veterinary students agreed that it is ethical to dissect animal cadavers. $67 \%$ of students performed dissection during lab session. Not all students were prepared for dissection via reading dissector. Majority of students indicated that dissection of animal cadavers in small groups allowed them to discuss and learn more. Almost whole student showed their preferred to dissect animal cadavers under lecturer assistance and supervision. $86 \%$ of veterinary students found that dissection of animal cadavers were exciting. Most of students reported that dissection of dog cadavers made them to understand and lean the veterinary anatomy easily and better as it animal them for actually seeing the structures. $79 \%$ of students mentioned that their preferability to dissect animal cadavers by themselves than prosected specimens. Moreover, the majority of students disagreed with replacing animal cadavers with plastic models and computer assisted demonstrations. Most of students wanted cadaveric dissection of animals to be continued in 
the veterinary gross anatomy syllabus as it will help them in other courses of the veterinary program (Table 1 \& Figure 1).

Table 1. Responses on attitude of veterinary students towards dissection of animal cadavers

\begin{tabular}{|c|c|c|c|}
\hline No. & Question & Yes & No \\
\hline 1 & Is animal cadaver dissection ethically acceptable? & $49(86 \%)$ & $8(14 \%)$ \\
\hline 2 & Did you perform cadaver dissection? & $38(67 \%)$ & $19(33 \%)$ \\
\hline 3 & $\begin{array}{l}\text { Did you spend time in reading dissection guide to } \\
\text { understand dissection of cadavers? }\end{array}$ & $32(56 \%)$ & $25(44 \%)$ \\
\hline 4 & $\begin{array}{l}\text { Was learning in small groups and interacting with your } \\
\text { peers during cadaver dissection more productive than } \\
\text { independent study? }\end{array}$ & $49(86 \%)$ & $8(14 \%)$ \\
\hline 5 & $\begin{array}{l}\text { Did you prefer to dissect with the assistance of your } \\
\text { lecturer? }\end{array}$ & $54(95 \%)$ & $3(5 \%)$ \\
\hline 6 & Did you find cadaver dissection exciting? & $50(86 \%)$ & $7(12 \%)$ \\
\hline 7 & $\begin{array}{l}\text { Did cadaver dissection make veterinary anatomy easier } \\
\text { to learn, study and understand? }\end{array}$ & $52(91 \%)$ & $5(9 \%)$ \\
\hline 8 & $\begin{array}{l}\text { Did cadaver dissection by you give better results and } \\
\text { understanding than demonstration on prosected } \\
\text { specimens? }\end{array}$ & $45(79 \%)$ & $12(21 \%)$ \\
\hline 9 & $\begin{array}{l}\text { Do you think that cadaver dissection should be replaced } \\
\text { by plastic models and computer assisted training? }\end{array}$ & $15(26 \%)$ & $42(74 \%)$ \\
\hline 10 & $\begin{array}{l}\text { Do you think that cadaver dissection is an important part } \\
\text { of the DVM degree? }\end{array}$ & $53(93 \%)$ & $4(7 \%)$ \\
\hline 11 & $\begin{array}{l}\text { Is performing cadaver dissection and actually seeing the } \\
\text { structures while you dissect help you learn anatomy } \\
\text { better? }\end{array}$ & $53(93 \%)$ & $4(7 \%)$ \\
\hline 12 & $\begin{array}{l}\text { Do you think cadaver dissection should be continued in } \\
\text { the anatomy syllabus? }\end{array}$ & $55(96 \%)$ & $2(4 \%)$ \\
\hline 13 & $\begin{array}{l}\text { Do you think cadaver dissection helps in learning other } \\
\text { DVM subjects? }\end{array}$ & $55(96 \%)$ & $2(4 \%)$ \\
\hline
\end{tabular}




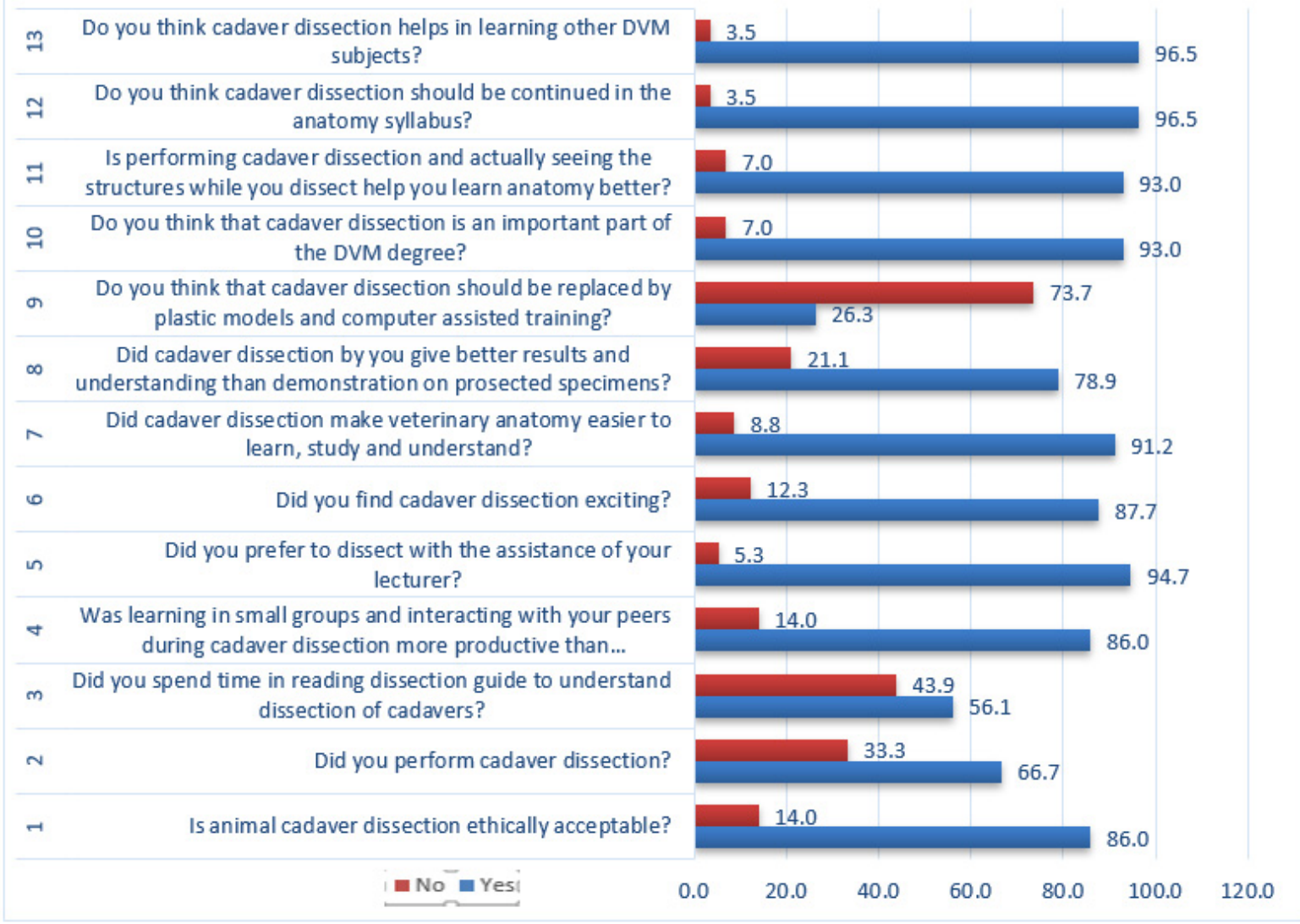

Figure 1. A graph showing the percentage of students' response to each question

\section{Discussion}

The current investigation as well as Bharadwaja and Aman (2017)) revealed that anatomy courses are special subjects that need to be studied using textbooks and cadaveric dissections.

Dissection of cadavers remains an effective method for basic anatomy teaching and it helps them to learn and understand anatomy deeply (Entwistle \& Tait, 1995; Wyk \& Rennie, 2015; Prabodha, Nanayakkara, Ilayperuma, Samarawickrama, \& Johnson, 2016; Bhimalli, Virupaxi, Pattanshetti, \& Siddibhavi, 2017; Küçükaslan, Erdoğan, \& Bulut, 2019).

Another interesting observation in the current study is that the majority of students preferred to dissect animal cadavers rather than look on at a demonstration on a prosected specimen; a similar result was obtained by Izunya, Oaikhena, and Nwaopara (2010). Students who preferred to dissect by themselves indicated that dissection of animal cadavers allowed them to better understand and recall, as well as to enhance their practical skills. While, students who preferred pre-dissected specimens indicated that it was clear and save time so that they would better utilize their time studying the specimens and they could be as a guide for dissection. However, the current result is contrary to that of Nnodim (1990) and Dinsmore (1999).

The current study as well as Prabodha, Nanayakkara, Ilayperuma, Samarawickrama and Johnson (2016) showed that students benefited in learning anatomy by working together in a small groups and interacting with peers during dissection than independent dissection. 


\section{MlMacrothink}

International Research in Education

ISSN 2327-5499

2020, Vol. 8, No. 1

The current study as well as Sharma, Subedi and Pandit (2017) showed that majority of the students under study disagree about replacement of cadaveric dissection by plastic models and computer assisted training. On the other hand, students who agreed to replace the animal cadavers by new technology and did not dissect animal cadavers indicated that plastinated models are more ethical and distinguishable; in addition they disagreed about the idea of killing animals for teaching purposes. Moreover, the computer assisted learning can enhance cadaveric dissection rather than its replacement (Rao, Swamy, \& Thomas, 2018).

The present investigation as well as Rajkumari and Singh (2007) and Izunya, Oaikhena, and Nwaopara (2010) reported that that students preferred dissection of cadavers under supervision of the lecturer, so as to avoid dissection errors.

The present results as well as Rao, Swamy and Thomas (2018) and Gummery, Cobb, Mossop and Cobb (2018) stated that dissection of cadavers allowed students to gain basic skills of surgery such as handling of surgical instruments.

The current study as well as Ganguly, Kawareti and Gedam (2018) suggested that animal cadavers should be obtained from humane and ethical sources such as animals that died from natural causes or euthanized due to unrecoverable injuries.

\section{Conclusion}

Dissection of animal cadavers remains the pillar and an integral part of veterinary anatomy teaching and learning by anatomists and veterinary students. Learning of veterinary anatomy was more conductive by dissection of animal cadavers in small groups and under lecturer supervision. Plastination and computer training programs cannot completely replace traditional dissection of animals. Therefore dissection of animal cadavers should be continued in the veterinary anatomy syllabus once ethical approval is given.

\section{References}

Azis, M. A., Mckenzie, J. C., Wilson, J. S., Cowie, R. J., Ayeni, S. A., \& Dunn, B. K. (2002). The human cadaver in the age of biomedical informatics. Anat Rec, 269, 22-32. https://doi.org/10.1002/ar.10046

Bharadwaja, A., \& Aman, M. (2017). Cadaveric Dissection - its importance and students response: a questionnaire study. International Journal of Scientific Study, 5(2), 252-255.

Bhimalli, S., Virupaxi, R. D., Pattanshetti, S., \& Siddibhavi, M. (2017). Perception of students towards the cadaveric dissection. Indian Journal of Basic and Applied Medical Research, 6(2), 156-159.

Dinsmore, C. E., Daugherty, S., \& Seitz, H. J. (1999). Teaching and learning gross anatomy; Dissection, protection, or both of the above? Clin Anat, 12, 110-14. https://doi.org/ 10.1002/(SICI)1098-2353(1999)12:2<110::AID-CA5>3.0.CO;2-3

Entwistle, N., \& Tait, H. (1995). Approaches to studying and perceptions of the learning environment across disciplines. New Dir Teach Learn, 64, 93-103. https://doi.org/10.1002/ t1.37219956413

Ganguly, S., Kawareti, \& Gedam, P. M. (2018). Alternative sources of animals in veterinary education: a review. In book: Advances in Veterinary Sciences, Vol 1, Chapter 6, AkiNik Book Publications, Rohini, Delhi, India. (pp. 126-127). 


\section{Al Macrothink}

International Research in Education

ISSN 2327-5499

2020, Vol. 8, No. 1

Gummery, E., Cobb, K. A., Mossop, L. H., \& Cobb, M. A. (2018). Student Perceptions of Veterinary Anatomy Practical Classes: A Longitudinal Study. J Vet Med Educ, 45(2), 163-176. https://doi.org/10.3138/jvme.0816-132r1

Izunya, A. M., Oaikhena, G. A., \& Nwaopara, A. O. (2010). Attitudes to cadaver dissection in a Nigerian medical school. Asian Journal of Medical Sciences, 2(3), 89-94.

Küçükaslan, Ö., Erdoğan, S., \& Bulut, İ. (2019). Turkish undergraduate veterinary students' attitudes to use of animals and other teaching alternatives for learning anatomy. $J$ Vet Med Educ, 46(1), 116-127. https://doi.org/10.3138/jvme.0217-032r1

McLachlan, J. C, Bligh, J., Bradley, P., \& Searle, J. (2004). Teaching anatomy without cadavers. Med Educ, 38(4), 418-24. https://doi.org/10.1046/j.1365-2923.2004.01795.x

Nnodim, J. O. (1990). Learning Human Anatomy: By Dissection or From Prosections? Med Educ, 24(4), 389-95. https://doi.org/10.1111/j.1365-2923.1990.tb02456.x

Ozkadif, S., \& Eken, E. (2012). Modernization process in veterinary anatomy education. Energy Education Science and Technology Part B: Social and Educational Studies, 4(2), 957-962.

Prabodha, L. B. L., Nanayakkara, B. G., Ilayperuma, I., Samarawickrama, M. B., \& Johnson, P. (2016). Is the cadaver dead? learning anatomy beyond the horizon. International Journal of Advances in Science Engineering and Technology, 4(1), 57-61.

Rajkumari, A. B., \& Singh, Y. I. (2007). Body donation and its relevance in anatomy learning - A review. J Anat Soc India, 56(1), 1-6.

Rao, S. R., Swamy, G., Thomas, L. R. (2018). Perception of interns towards cadaveric dissection V/s computer assisted anatomy teaching. World Journal of Pharmaceutical and Medical Research, 4(6), 264-267.

Sharma, N., Subedi, S., \& Pandit, R. (2017). Medical students' attitude towards anatomy dissection: a study from Nepal. Journal of Universal College of Medical Sciences, 5(2), 12-17. https://doi.org/10.3126/jucms.v5i2.19157

Woon, S. Y. A. (2011). Veterinary student's perspective on educational animal use and the potential for humane alternatives. ALTEX Proceedings, 1/12, Proceedings of WC8: (pp. 377-385).

Wyk, J. V., \& Rennie, C. O. (2015). Learning anatomy through dissection: Perceptions of a diverse medical student cohort. Int J Morphol, 33(1), 89-95. https://doi.org/10.4067/ S0717-95022015000100015

\section{Copyright Disclaimer}

Copyright reserved by the authors.

This article is an open-access article distributed under the terms and conditions of the Creative Commons Attribution license (http://creativecommons.org/licenses/by/3.0/). 